Agro-Science Journal of Tropical Agriculture, Food, Environment and Extension Volume 13 Number 2 May 2014 pp. 7 - 16

ISSN III9-7455

\title{
PHYSICAL AND FUNCTIONAL PROPERTIES OF BREAKFAST CEREALS FROM MAIZE, AFRICAN YAM BEAN AND COCONUT CAKE
}

\author{
Okafor G. I. ${ }^{1}$ and G. O. Usman ${ }^{2}$ \\ ${ }^{1}$ Department of Food Science and Technology, University of Nigeria, Nsukka, Enugu State, Nigeria. \\ ${ }^{2}$ Department of Food, Nutrition and Home Sciences, Kogi State University, Anyingba, Kogi State, \\ Nigeria email:gabriel.okafor@unn.edu.ng;
}

\begin{abstract}
The physical and functional attributes of ready-to-eat breakfast cereals produced from blends of maize (Zea mays), African yam bean (Sphenostylis stenocarpa) (AYB), defatted coconut (Cocos nucifera) cake and sorghum (Sorghum bicolor L. Moench) malt extract, were evaluated, to generate essential data on the products. Six samples were formulated by mixing the AYB and maize composite flour with graded levels of defatted coconut (100:0, 90:10, 80:20, 70:30, 60:40, 50:50), sugar, salt and water. The samples were mixed and toasted at $280^{\circ} \mathrm{C}$ for 5mins each in a non-stick metallic pan, cooled and packaged. The results revealed the following ranges of physical and functional properties; $\mathrm{pH}(4.70-6.56)$, bulk density $(0.29-0.71 \mathrm{~g} / \mathrm{ml})$, water absorption capacity (68.31- 76.39\%), oil absorption capacity (0.87- 1.32\%), foam capacity (2.48- 3.49\%), viscosity (19.73-31.08\%), gelation temperature $\left(121-157^{\circ} \mathrm{C}\right)$, emulsification capacity $(5.79-9.86 \mathrm{~g} / 100 \mathrm{~g})$, wettability $(15.67-23.22 \mathrm{sec}$.) and invitro-protein digestibility (66.30-82.2\%). It is evident that there are significant variations of physical and functional attributes with addition of defatted coconut fibre in the formulations.
\end{abstract}

Key words: Bulk density, water absorption capacity, foam capacity, viscosity, gelation capacity

\section{INTRODUCTION}

Ready-to-eat breakfast cereals are increasingly gaining acceptance in most developing countries, and gradually displacing most traditional diets that serve as breakfast, especially amongst urban dwellers, due to convenience, improved income, nutritional values, status symbol and job demands. According to Jones (2003) ready-to-eat (RTE) cereals facilitate independence because of their ease of preparation which means that children and adolescents can be responsible for their own breakfast or snacks. Such foods may need to be reconstituted, pre-heated in a vessel or allowed to thaw if frozen before consumption, or they may be eaten directly without further treatment (Okaka, 2005). Their consumption has also been extended to non-breakfast hours and often serve as in-between meals. A study has clearly shown that $42 \%$ of 10 -year-olds and $35 \%$ of young adults consumed cereal at non-breakfast occasions (Haines et al 1996), and could be taken dry as snack food, with or without cold or hot milk, based on their location, availability of resources and habits.

In recent times, food product developers have incorporated legumes into traditional cereal formulations as nutrient diversification strategy as well as an effort to reduce the incidence of malnutrition among vulnerable groups. Results from previous studies indicated that most cereals are limited in some essential amino acids especially threonine and tryptophan even though rich in lysine (especially the yellow maize) (Onweluzo and Nnamuchi, 2009). Whole maize contains about $11 \%$ protein, $4 \%$ fat, $3 \%$ fibre, $65 \%$ of starch and other carbohydrates and $1.5 \%$ of minerals (Ihekoronye and Ngoddy, 1985). Thus maize cannot effectively provide the nutrients required by the body, especially in the morning when the supply of nutrients from the previous day is exhausted. On the other hand, sorghum starch has been shown to possess the same functional characteristics with corn starch (Perez-Sira et al 1997). It has better agronomic

http://dx.doi.org/10.4314/as.v13i2.2 
properties due to high drought tolerance and could prove to be a beneficial crop in future with increase in world population (Singh and Singh, 1995). Sorghum starch could be modified by malting inorder to generate an extract that will improve product acceptability. Cereals such as maize and sorghum are rich in sulphurcontaining essential amino acids such as methionine, cysteine and tryptophan, while the storage proteins of most oil seeds and legumes are relatively low in sulphur-containing amino acids, but very high in another essential amino acid, lysine compared to cereals (Rockland and Radke, 1981; Kanu et al 2009). Relative to lysine and sulphur amino acid contents, legume and cereal proteins are nutritionally complementary, depending on the contents of the second limiting amino acids, i.e., threonine in cereals and tryptophan in legumes (Duranti, 2006). Therefore, a combination of such food stuffs will improve the nutritional value of the resulting blend, compared to the individual components alone. The source of vegetable protein ranges from the highly utilized and popular legumes such as soybeans to the lesser known ones like African yam beans (Sphenostylis stenoscarpa) (AYB) (Udensi et al 2010). The amino acid values in AYB seeds are higher than those in pigeon pea, cowpea, and Bambara groundnut (Uguru and Madukaife, 2001). Coconut flour is usually obtained from coconut cake, which is the byproduct of coconut milk production that is posing a tremendous disposal challenge to processors, who are currently searching for its novel use (Jena and Das, 2007). Coconut presscake has been dried and milled into flour for use in preparation of several food products (Hagenmier, 1983). However, the ultimate success of utilizing plant protein in food formulation depends largely upon the functionality (Maruatona, 2008) which is the property of a food ingredient that determines its usefulness in food systems (Fennema, 1996), as well as their physical attributes, which may be customized by incorporating other raw materials. A combination of seed legumes, cereals and dietary fibre source is likely to yield products with nutritionally higher quality than that produced from individual component. These components also have the potentials to blend properly giving a desirable mouth feel and taste appeal due to their functional and physical attributes. According to Van Soest et al (1991) the physical and biological properties of carbohydrate fractions are more important than their intrinsic composition. Therefore, the physical properties of some agricultural produce and their products have been intensely studied by researchers. Matthey and Hanna, (1997) determined several physico-chemical and functional properties of corn starch-WPC extrudates. Haralampu, (2000) reviewed the physical properties and biological impact of resistant starch for production of extruded diabetic products. Sacchetti et al (2004), investigated the effects of chestnut flour content and extrusion temperature on the functional and physical properties of rice flour-based extrudates. On the other hand, Bagherpour et al (2010) studied the physicomechanical properties of lentil seed, while Adejumo et al (2005) studied that of bambara groundnut and BartPlange and Baryeh, (2003) cocoa bean. TaheriGaravand et al 2012 investigated the effect of moisture content on the post-harvest physical and mechanical properties of hemp seed in the range of 5.39 to $27.12 \%$ d.b.

This study was therefore aimed at determining some physical and functional properties of breakfast cereals produced from blends of maize, AYB and defatted coconut flours.

\section{MATERIALS AND METHODS}

Maize grains, African yam bean (AYB) seeds and mature coconuts as well as other ingredients such as sugar, salt, sorghum were purchased from Ogige market, Nsukka in Enugu State, Nigeria.

Maize grains $(5 \mathrm{~kg})$ were cleaned, sorted and milled into flour using attrition mill (Ihekoronye and Ngoddy 1985). The brown African yam bean seeds $(5 \mathrm{~kg})$ milled into flour using attrition mill as described in Okafor and Usman, (2013). Freshly dehusked coconuts (Cocus nucifera) weighing $4 \mathrm{~kg}$ were properly cleaned and cracked to expel the containing coconut juice/water. The coconut flesh (meat) was removed from the shell with the aid of a sharp pointed knife. The brown colour of the skin was scraped off with a knife. The coconut flesh was milled with an attrition mill and the slurry was defatted according to the method of Sanful (2009). The obtained cake was dried, milled, sieved using $0.5 \mathrm{~mm}$ mesh sieve, packaged in polyethylene bags prior to use. Cleaned and sorted white sorghum (Sorghum bicolor L.) seeds ( $5 \mathrm{~kg}$ ) were steeped in tap water for $18 \mathrm{~h}$ and germinated on floor for three days at room temperature $\left(30 \pm 2^{\circ} \mathrm{C}\right)$ and used to produce sorghum malt extract as described by Okafor and Aniche, (1980). AYB and maize composite flour was prepared by mixing $40 \%$ maize with $60 \%$ AYB flour. The defatted coconut flour was then used to substitute $10,20,30,40$ and $50 \%$ of the maize AYB blend. The blends were roasted at $280^{\circ} \mathrm{C}$ in a Teflon surface with continuous stirring till dried readyto-eat granules of each of the five samples were obtained as explained in Okafor and Usman, (2013). A control sample was produced from $100 \%$ maize and African yam bean composite flour. The flow chart for production of the breakfast cereals is presented in Fig. 1.

The $\mathrm{pH}$ of the food samples was measured with a Mettler Delta $350 \mathrm{pH}$ meter using the method 
described by Onwuka (2005). The sample homogenate was prepared by blending $10 \mathrm{~g}$ sample in $100 \mathrm{ml}$ of deionized water. The mixture was filtered and the $\mathrm{pH}$ of the filtrate measured. Bulk density was determined for each of the formulated samples using the method described by Onwuka (2005). Each sample was filled into $10 \mathrm{ml}$ measuring cylinder. The bottom of the cylinder was gently tapped on a laboratory bench until there is no further diminution of the sample after filling to $10 \mathrm{ml}$ mark. Bulk density was estimated as mass per unit volume of the sample $(\mathrm{g} / \mathrm{ml})$.

The water and fat absorption capacities, foam and emulsification capacities as well as gelatinization temperature, wettability and viscosity of the breakfast cereals were determined using the methods described by Onwuka (2005). Oswald viscometer was used to measure the viscosity of $10 \%$ of each sample, which was suspended in distilled water and mechanically stirred for 2 hours at room temperature. The invitroprotein digestibility of each sample was determined using the method described by Kanu et al (2009).

The experiment followed a completely randomized design (CRD). One way analysis of variance (ANOVA) was conducted, and the means were separated by Duncan's new multiple range test (DNMRT) using the Statistical Package for Social Sciences (SPSS) version 16. The level of significance was accepted at 0.05 probability level.

\section{RESULTS AND DISCUSSION}

The physical properties of the developed breakfast cereals are shown in Figs. 2 and 3. The $\mathrm{pH}$ values of the products (Fig. 2) which ranged from $4.70 \pm 0.01$ to $6.56 \pm 0.01$ showed that there were no significant ( $>0.05$ ) differences between samples 70:30, 60:40 and 50:50 (African yam bean-maize composite: defatted coconut flour formulations), as well as between samples 90:10 and 80:20 (African yam bean-maize composite: defatted coconut flour formulations), while there was significant $(\mathrm{p}<0.05)$ difference in the $\mathrm{pH}$ of 100:0 formulation and the other samples. Agunbiade and Ojezele (2010) recorded 4.88 for $\mathrm{pH}$ of fortified breakfast cereal from maize, sorghum, AYB and soybeans. The low acid $\mathrm{pH}$ range observed in this study may be due to partial hydrolysis which probably occurred during soaking of the legume. The higher $\mathrm{pH}$ values recorded for the samples with high level of defatted coconut flour $(20-50 \%)$ may be as a result of the low acid nature of coconut, whose $\mathrm{pH}$ ranges from 5.5 to 7.8 (Anon, 2013). Food products developed with coconut flour provide health benefits like lowering of blood cholesterol or preventing cancer, aside from its nutritional contribution (Capanzana et al 2013). The high $\mathrm{pH}$ value of these breakfast cereals will help to balance the consumer's body pH. McCarron (2011) reported that eating low acid foods will help to avoid or at least lessen the likelihood of encountering many health problems associated with an overly acidic system that are linked to heart disease, obesity, cancer, fatigue, allergies and premature aging. The bulk density of the breakfast cereals (Fig. 3) ranged from $0.17 \pm 0.01 \mathrm{~g} / \mathrm{ml}$ to $0.29 \pm 0.01 \mathrm{~g} / \mathrm{ml}$ with the highest value found in the sample 100:0 formulation. There was a gradual reduction of the bulk density with increase in the addition of defatted coconut flour content although samples 90:10, 80:20, 70:30 (African yam bean-maize composite: defatted coconut flour) were not significantly $(\mathrm{p}>0.05)$ different from each other. Higher values of bulk density $(2.45 \pm 0.10$ and $2.60 \pm 0.05)$ were recorded by Agunbiade and Ojezele (2010) for fortified breakfast cereals made from maize, sorghum, AYB and soybeans. Sivetz and Desrosier (1979) reported bulk density ranges of $0.31-0.40 \mathrm{~g} / \mathrm{ml}$ and $0.20-0.43 \mathrm{~g} / \mathrm{ml}$ for roasted ground coffee and instant coffee powder respectively. The bulk densities suggest that the samples may require different packaging space. The less the bulk density, the more packaging space is required (Agunbiade and Ojezele, 2010). However, Rao (2007) observed that considerable variation in the magnitudes of bulk densities can result due to vibration, different particle sizes, and other factors. Sivetz and Desrosier (1979) further revealed that due to the presence of greater wall support, the bulk density of roasted and ground coffee is lower in vessels less than $30 \mathrm{~cm}$ than in larger diameter vessels, while finer grinds form denser beds. The dielectric loss factor of granulated foods has been shown to be dependent on bulk density (Calay et al, 1995). Sahin and Sumnu (2006) established a directly proportional relationship between them, hence, the lower the bulk density, the lower the loss factor observed.

The functional properties of the breakfast cereals are presented in Table 2 and Figs. 4-7. 


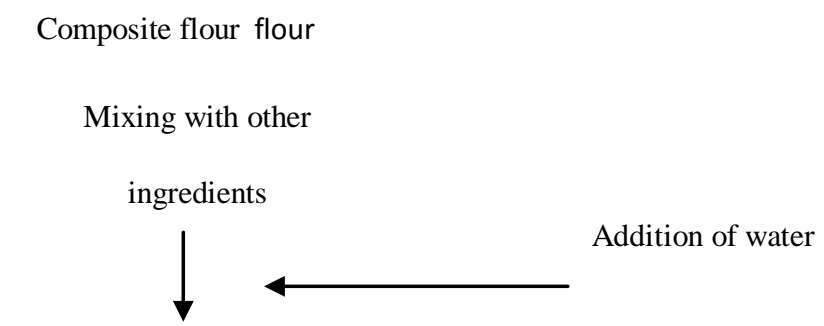

Toasting $\left(280^{\circ} \mathrm{C}, 5 \mathrm{mins}\right)$

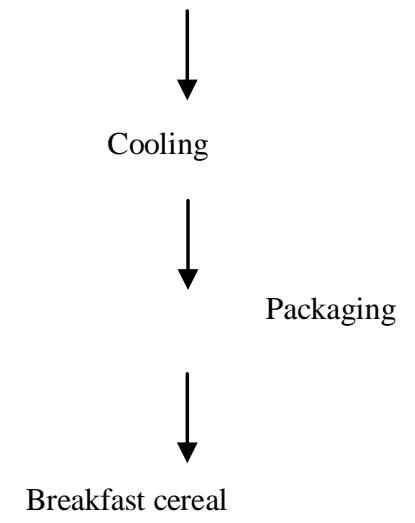

Fig. 1. Production of African yam bean + maize: defatted coconut flour breakfast cereals

Table 1. Functional properties of breakfast cereals from blends of AYB+maize: defatted coconut

\begin{tabular}{|c|c|c|c|c|c|}
\hline Sample & $\begin{array}{c}\text { WAC } \\
(\%)\end{array}$ & $\begin{array}{c}\text { FAC } \\
(\%)\end{array}$ & $\begin{array}{l}\mathrm{FC} \\
(\%)\end{array}$ & $\begin{array}{c}\text { Viscosity } \\
\text { (cps) }\end{array}$ & $\begin{array}{l}\mathrm{GC} \\
(\%)\end{array}$ \\
\hline 100:0 & $68.32 \pm 0.01^{f}$ & $1.32 \pm 0.01^{\mathrm{a}}$ & $3.49 \pm 0.01^{\mathrm{a}}$ & $31.08 \pm 0.01^{\mathrm{a}}$ & $89.66 \pm 0.01^{\mathrm{a}}$ \\
\hline $80: 20$ & $71.24 \pm 0.01^{\mathrm{d}}$ & $1.07 \pm 0.01^{\mathrm{c}}$ & $3.25 \pm 0.01^{\mathrm{ab}}$ & $26.41 \pm 0.01^{\mathrm{b}}$ & $81.4 \pm 30.01^{\mathrm{c}}$ \\
\hline $70: 30$ & $74.81 \pm 0.05^{\mathrm{c}}$ & $0.96 \pm 0.01^{\mathrm{d}}$ & $2.80 \pm 0.01^{\mathrm{b}}$ & $24.22 \pm 0.01^{\mathrm{c}}$ & $78.56 \pm 0.01^{\mathrm{d}}$ \\
\hline $60: 40$ & $75.43 \pm 0.01^{b}$ & $0.93 \pm 0.01^{\mathrm{e}}$ & $2.63 \pm 0.01^{\mathrm{e}}$ & $21.98 \pm 0.01$ & $77.34 \pm 0.01^{\mathrm{e}}$ \\
\hline $50: 50$ & $76.39+0.06^{\mathrm{a}}$ & $0.87 \pm 0.01^{\mathrm{f}}$ & $2.48 \pm 0.01^{\mathrm{f}}$ & $19.73+0.01^{\mathrm{e}}$ & $75.32+0.01^{\mathrm{f}}$ \\
\hline
\end{tabular}

Values are means \pm SD of triplicate determinations. Means differently superscripted along the vertical columns are significantly different $(\mathrm{p}<0.05)$.

WAC: water absorption capacity

FAC: oil absorption capacity

FC: foam capacity

GC: gelation capacity

The water absorption capacity (WAC) of the formulated breakfast cereals (Table 1) ranged from $68.31 \pm 0.01$ to $76.39 \pm 0.01 \%$. The WAC increased with increase in defatted coconut flour inclusion. This may be due to the hygroscopic properties of coconut, thus, swelling on exposure to moisture (Wasserman, 2010). Similar values were recorded from treated and untreated sorghum and pigeon pea breakfast cereals (Mbaeyi, 2005). On the other hand, water absorption capacity of the breakfast cereals may equally be associated with the nature of starch granules after toasting. According to Greer and Stewart (1959), water absorbtion capacity is influenced by the degree of disintegration of native starch granules. Considering the temperature of toasting that was approximately $280^{\circ} \mathrm{C}$ and variation of starch content of each formulation with increasing addition of coconut fiber, damaged starch is likely to increase and will require more fluid such as water or milk on reconstitution. The oil absorption capacity (FAC) of the breakfast cereals (Table 1) varied in trend as those obtained for water absorption capacity. The values ranged from 
$0.87 \pm 0.01$ to $1.32 \pm 0.01 \%$ with the highest value recorded for 100:0 formulation. There were significant differences $(\mathrm{p}<0.05)$ among all the samples. The FAC decreased with increasing addition of defatted coconut flour. The hydrophobicity of proteins is known to play a major role in fat absorption. This helps to resist physical entrapment of oil by the capillary of non-polar side chains of the amino acids of protein molecules (Chau and Cheung, 1998).

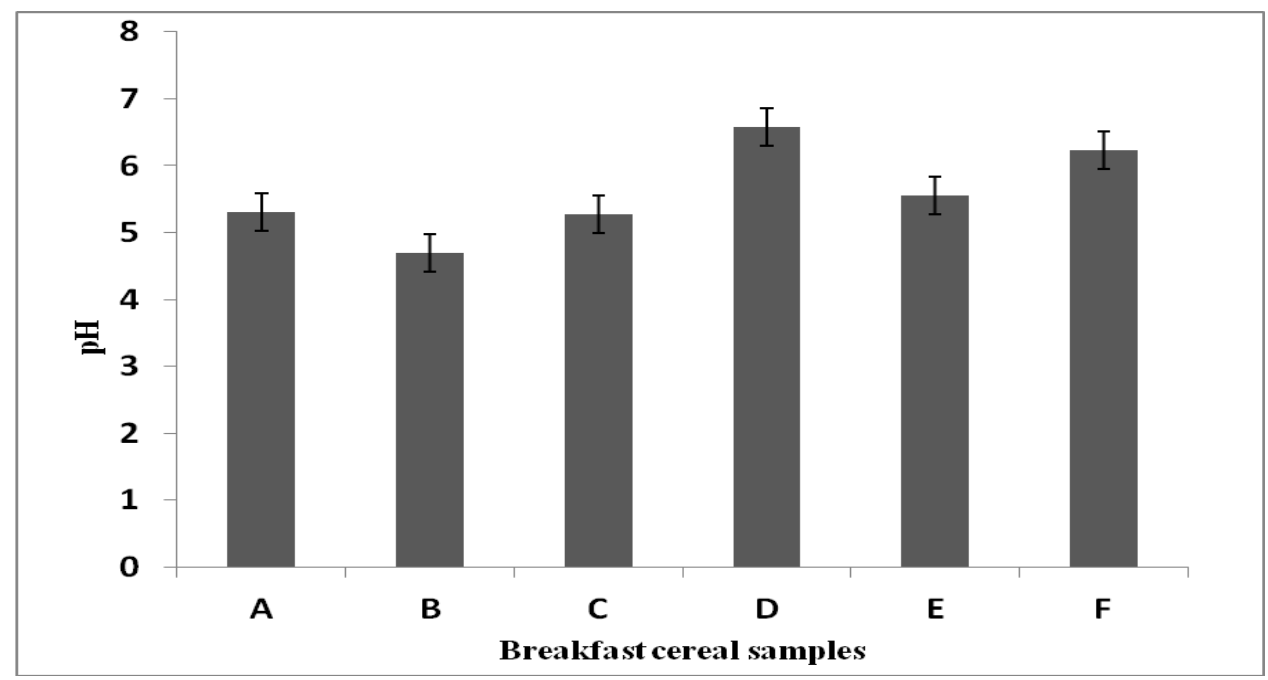

Fig. 2. $\mathrm{pH}$ values of breakfast cereals from blends of AYB+Maize: Defatted coconut flour $\mathrm{A}=100: 0 \quad, \mathrm{~B}=90: 80, \mathrm{C}=80: 20, \mathrm{D}=70: 30, \mathrm{E}=60: 40, \mathrm{~F}=50: 50$

Sample ratio: AYB+Maize: Defatted coconut flour

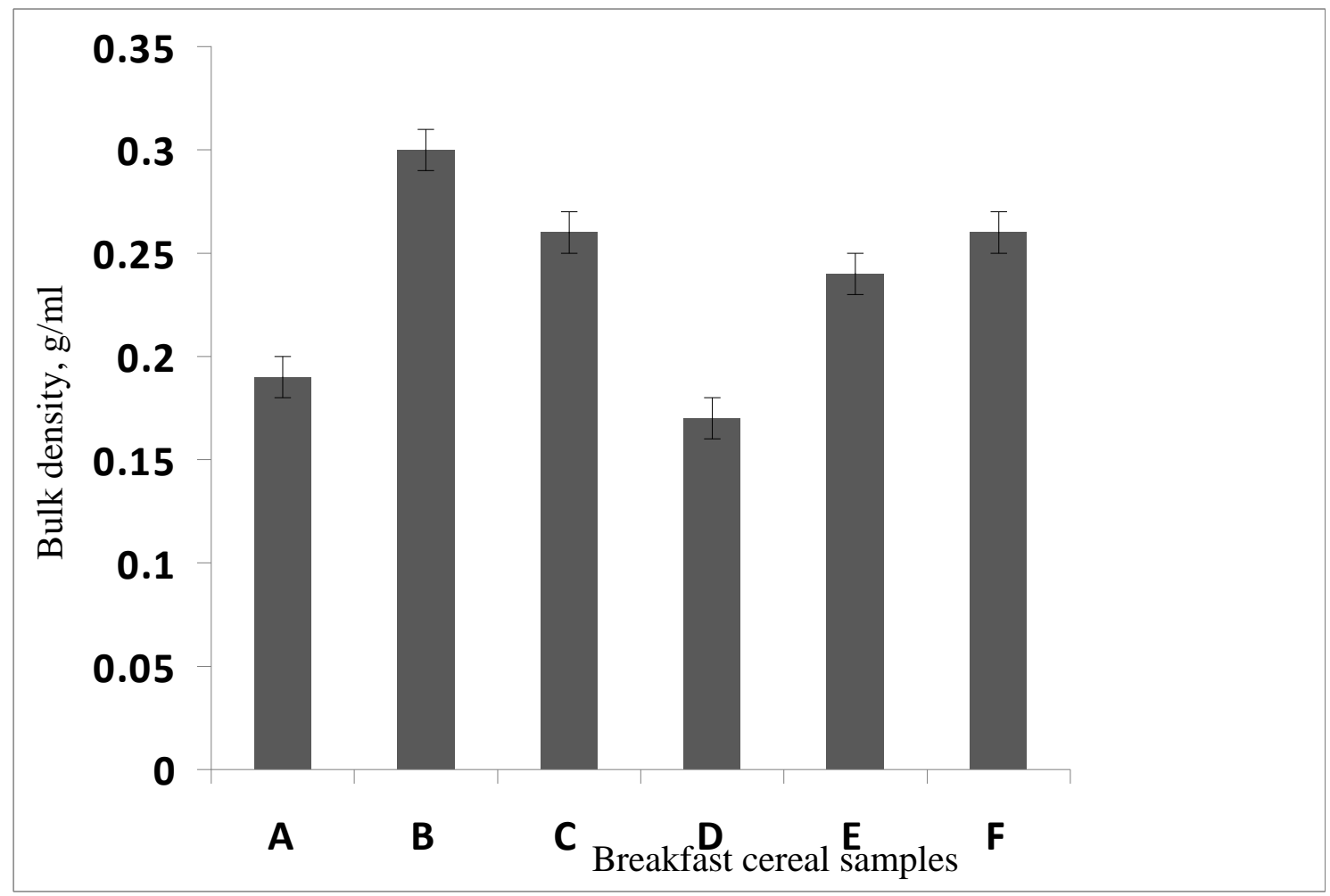

Fig. 3. Bulk density of breakfast cereals from blends of $A Y B+$ Maize: Defatted coconut flour $\mathrm{A}=100: 0 \quad, \mathrm{~B}=90: 80, \mathrm{C}=80: 20, \mathrm{D}=70: 30, \mathrm{E}=60: 40, \mathrm{~F}=50: 50$

Sample ratio: AYB+Maize: Defatted coconut flour 
The foam capacity of the samples (Table 1) ranged from $2.48 \pm 0.01$ to $3.49 \pm 0.01 \%$ with the highest value observed with 100:0 formulation. There was a gradual decrease in foam capacity with increasing addition of defatted coconut flour. This value was higher than those recorded for flour obtained from boiled AYB (1.98\%). Padmashree et al (1987) also reported the decreasing effect of processing conditions on foam capacity with processed cowpea flour. The more pronounced reduction in foam capacity in heat-treated (boiling and roasting) sample has been attributed to protein denaturation (Lin et al., 1974). It is also an indication of precipitation of proteins due to temperature and some heat treatment. The viscosity of the products (Table 1) ranged from $19.73 \pm 0.01$ to $31.08 \pm 0.01 \mathrm{cps}$, with the $50: 50$ formulation having the least value. The viscosity of the breakfast cereals decreased with increasing addition of defatted coconut flour. The generally low viscosity observed may be due to less disruption of intermolecular hydrogen bonds that brought about noticeable swelling of the granules and gelation (Ihekoronye and Ngoddy, 1985). Swelling of the granules was observed to be slight in cold water, compared to when placed in hot water. The breakfast cereals would be consumed depending on preferences or situations in various ways such as in cold water, hot water, cold and hot milk. The presence of defatted coconut flour enhanced water absorbtion and softening of the breakfast cereals. This is supported by Wasserman (2010), who reported that coconut fiber has a high water absorption capacity and easily dissolves in liquids, but does not thicken or gel. The wettability test in Fig. 4 showed that the particles of the formulated samples were totally hydrated between 15.67 to 23.22 seconds. This may be due to the small particle sizes of the samples, as well as the hygroscopic nature of the defatted coconut flour, which hastened hydration of the samples. The breakfast cereals wettability increased by allowing more water penetration within its matrix with increasing addition of defatted coconut flour. This may be due to increased fiber content that has been shown to retain water (Biswas et al, 2011), as a result of added defatted coconut flour. The toasting process and continuous stirring which helped to dehydrate and agglomerate the particles upon gelatinization into small aggregates also contributed in making them to be readily covered by fluid during rehydration. The particles sank, absorbed water and dispersed upon stirring. Hence, the characteristics such as wettability, sinkability, dispersibility, and solubility required from instantized products (APV, 2000; Hogekamp and Schubert, 2000), were met within some seconds. The gelation temperature of the breakfast cereals in Fig. 4 ranged from $121^{\circ} \mathrm{C}$ to $157^{\circ} \mathrm{C}$. Gelation temperature of the samples generally decreased with increasing addition of defatted coconut flour. Increasing fiber content appears to delay gelation and subsequently its temperature, implying that lesser amount of energy will be spent in processing the samples with higher levels of coconut fibre addition. However, Wasserman (2010) observed that defatted coconut; even when dissolved in water does not thicken or gel. Thus, higher heat energy is required to attain significant gelation. Gelling temperature might be associated with the relative ratio of amylase and amylopectin (Ayenor, 1985), in the composite flour. Case et al (1996) reported that waxy and regular maize gelatinize at $62-72^{\circ} \mathrm{C}$, whereas highamylose starches begin to swell below $100^{\circ} \mathrm{C}$, temperatures greater than $130^{\circ} \mathrm{C}$ are required to fully disperse these starches. This is because more amylose molecules are involved in the crystalline regions of the high amylose starch than in waxy and regular starches (Shi et al, 1998). Case et al (1996) equally observed that low amylopectin starch formed acceptable gels throughout the temperature ranges of 121.1 to $165.6^{\circ} \mathrm{C}$. The emulsification capacity (EC) of the samples in Fig. 4 revealed values ranging from 5.77 to $7.41 \%$, with the highest value recorded for 100:0 formulation. Addition of defatted coconut flour led to reduction of the emulsification capacity. The EC is the ability of proteins to diffuse at the oil-water interface and to develop interlinkages with water and hydrophilic amino acids and oil with hydrophobic amino acids simultaneously (Asharaf et al.,, 2012). 


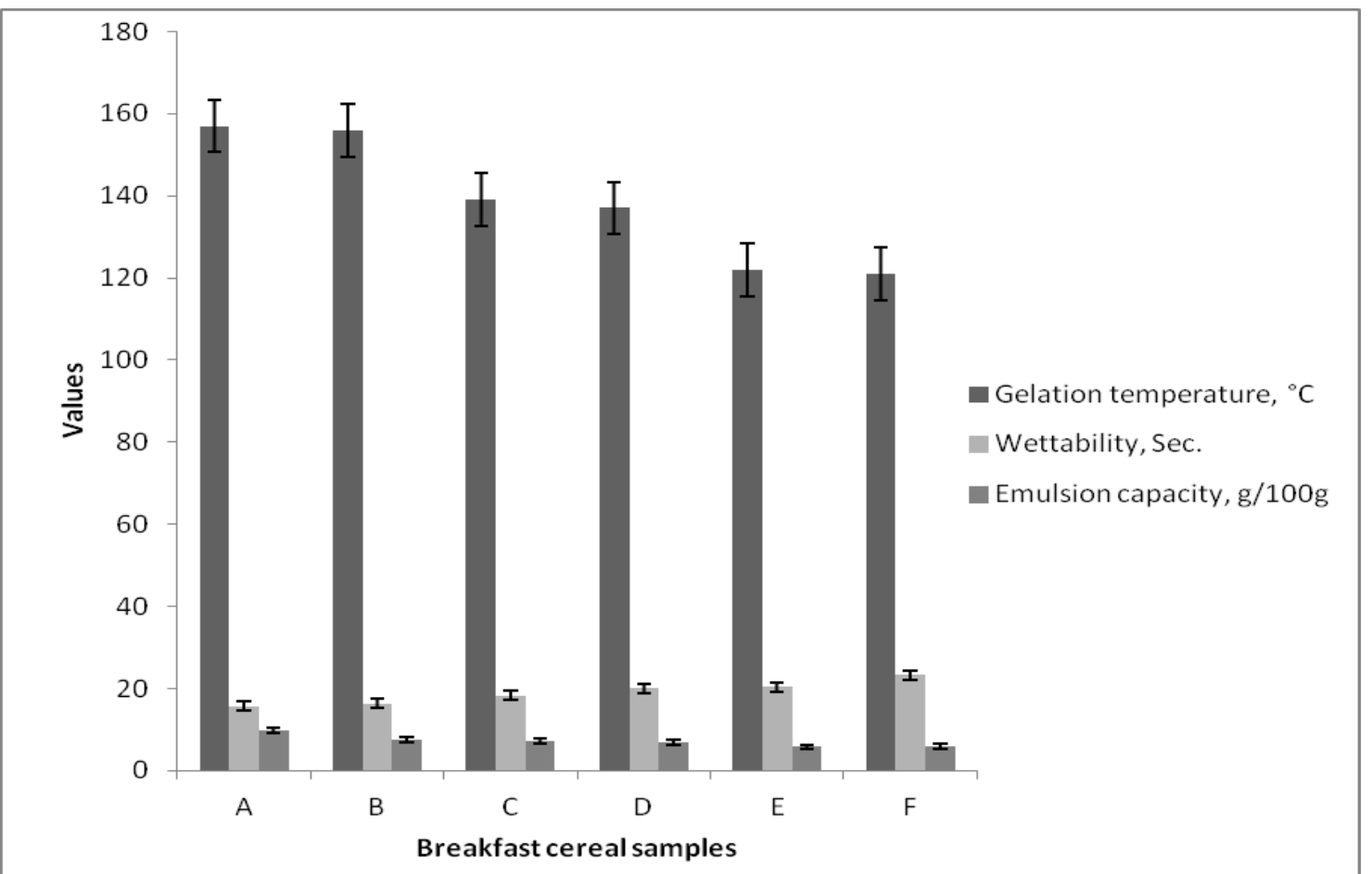

Fig. 4. Some functional properties of AYB + Maize: Defatted coconut flour breakfast cereals $A=100: 0, B=90: 80, C=80: 20, D=70: 30, E=60: 40, F=50: 50$

Sample ratio: AYB+Maize: Defatted coconut flour

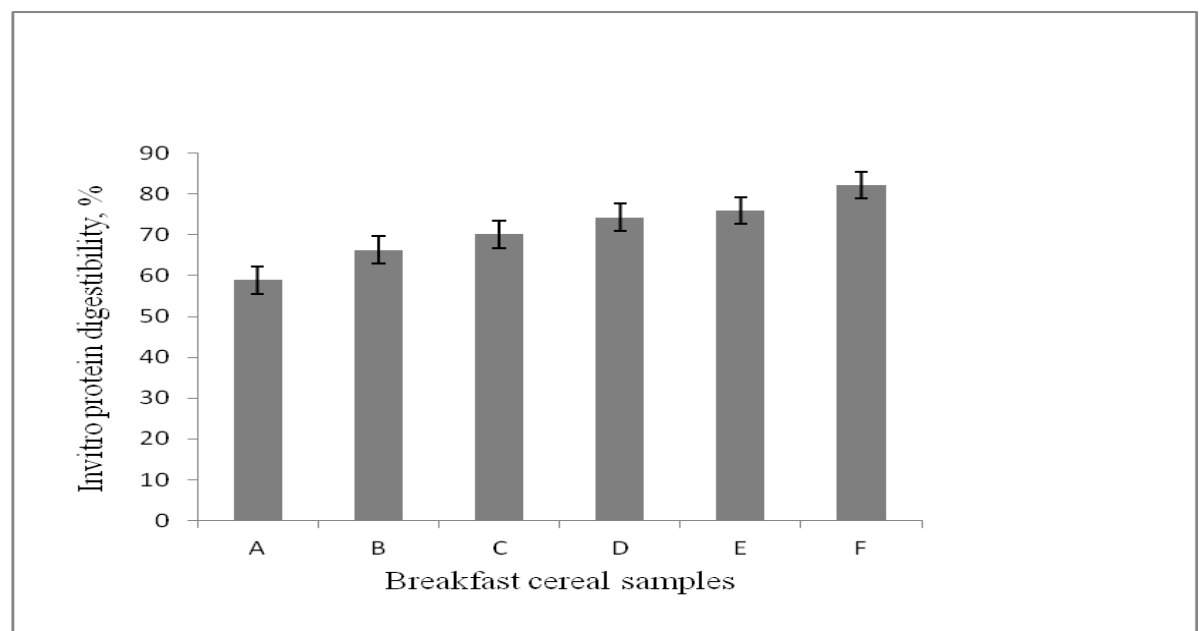

Fig.5. In-vitro protein digestibility of AYB+Maize:Defatted coconut flour breakfast cereals $\mathrm{A}=100: 0 \quad, \mathrm{~B}=90: 80, \mathrm{C}=80: 20, \mathrm{D}=70: 30, \mathrm{E}=60: 40, \mathrm{~F}=50: 50$

Sample ratio: AYB+Maize: Defatted coconut flour

The disparity in the EC values could be a reflection of their content of protein molecules that hangs oil and water droplets. The lower EC values of other samples could be as a result of their lower protein contents, which decreased from $18.26 \%$ in the control to the least value of $15.68 \%$ in 50:50 sample (Okafor and Usman, 2013). On the other hand, Arawande and Borokini, (2010) reported emulsion capacities of $71.73 \pm 0.44 \%, 28.73 \pm 0.12 \%$ and $46.40 \pm 0.22 \%$ for Jack bean, pigeon pea and cowpea respectively, with corresponding protein contents of $26.20 \pm 0.40 \%$, $24.46 \pm 0.32 \%$ and $24.13 \pm 0.31 \%$. The invitro-protein digestibility shown in Fig. 5, ranged from 66.30 \pm 0.01 to $82.2 \pm 0.01 \%$. The $50: 50$ formulation had the highest digestibility value. Invitro-protein digestibility reveals the dynamics of protein breakdown, which equally expresses the usefulness of the food to the body relative to its protein quality Sultana et al. (2010). The values recorded in this study shows that more protein was digested with increasing addition of coconut flour. 
This may be connected to the fact that fiber is known to aid digestion, and this might have led to the increase in digestibility of the proteins. Brule and Savoie (1988) studied the invitro protein digestibility of casein, field peas, peanut meal, wheat flour, rapeseed and soya bean concentrate and their blends (ratio 1:1) and observed that wheat flour had the lowest in vitro digestibility $(30 \%$ in $6 \mathrm{~h})$ while the other sources had similar digestibilities $(40 \%)$. Implying that combination of ingredients and production processes may increase invitro protein digestibility of the ensuing products, probably due to reduction of anti-nutritional factors amongst other factors. In-vitro protein digestibility is affected by many factors such as genotype, tannin content (Elsheikh et al., 1999) and thermal treatment (Wu et al., 1974) that makes proteins better available after heat treatment due to increased accessibility of protein to enzymatic attack (Van der Poel, 1990). On the other hand, the low digestibility of bean proteins has been attributed to factors such as the resistance of the major storage protein (phaseolin) to proteolysis and to the presence of fibre, tannins and other polyphenolic compounds in dry seeds, anti-nutritional compounds which can modify the digestibility, (Aw and Swanson, 1985) altering the liberation of amino acids and high excretion of endogenous nitrogen. The high level of invitro protein digestibility of the samples indicates the bioavailability of their proteins critical for the supply of amino acids in the products as well as their utilization on consumption.

\section{CONCLUSION}

This study revealed that addition of defatted coconut flour to the formulation increased the $\mathrm{pH}$ value of the breakfast cereals. The bulk density reduced with increase in the addition of defatted coconut flour content although the samples 90:10, 80:20, 70:30 (African yam bean-maize composite: defatted coconut flour) formulations were not significantly $(p>0.05)$ different from each other. The WAC increased with increase in defatted coconut flour inclusion. The FAC decreased with increasing addition of defatted coconut flour. The foam capacity, gelation temperature, emulsification capacity and viscosity of the breakfast cereals decreased gradually with increasing addition of defatted coconut flour. Wettability of the breakfast cereals increased with increasing addition of defatted coconut flour.

The values recorded in this study shows that more protein was digested with increasing addition of coconut flour.

\section{REFERENCES}

Adejumo O.I., Alfa A.A., and Mohammed A., (2005). Physical properties of Kano white variety of bambara groundnut. Proc. Nigerian Institute of Agricultural Engineers 27:203-210, December 12-15, Yenegoa, Bayelsa State, Nigeria.

Agunbiade S.O. and Ojezele M.O., (2010). Quality evaluation of instant breakfast cereals fabricated from maize, sorghum, soybean and African yam bean (Sphenostylis stenocarpa). World J. Dairy and Food Sci. 5: 7-72.

Anon, (2013). Food and foodstuff - $\mathrm{pH}$ values.http://www.engineeringtoolbox.com/foo d-ph-d403.html. Assessed on 07-02-2013.

APV, (2000). Dehydration. In: F.J. Francis, ed. Wiley Encyclopedia of Food Science and Technology. New York: John Wiley and Sons. pp. 480 -578

Arawande J.O. and Borokini F.B., (2010). Comparative study on chemical composition and functional properties of three Nigerian legumes (jack beans, pigeon pea and cowpea). J. Emerg. Trends in Eng. and Appl. Sci., 1: 89-95.

Ashraf S., Saeed S.M.G., Sayeed S.A. and Ali R., (2012). Impact of microwave treatment on the functionality of cereals and legumes. Int. J. Agric. and Bio. 14,356-370.

Ayenor S.G., (1985). The yam (Discorea) starches in: Advances in yam research. Enugu, Nigeria: United Industries and Shipping Inc. pp. $79-$ 87.

Aw T.L. and Swanson B.G., (1985). Influence of tannin on Phaseolus vulgaris protein digestibility and quality. J. Food Sci., 50, 6771.

Bagherpour H., Minaei S. and Khoshtaghaza M. H., (2010). Selected physico-mechanical properties of lentil seed. Int. Agrophys, 24, 81-84.

Bart-Plange A. and Baryeh E.A., (2003). The physical properties of category B cocoa beans. J. Food Eng., 60: 219-227.

Biswas A.K., Kumar V., Bhosle S., Sahoo J. and Chatli M.K., (2011). Dietary fibers as functional ingredients in meat products and their role in human health. Int. J. Livestock Prod., 2:45-54.

Brulé D. and Savoie L., (1988). In vitro digestibility of protein and amino acids in protein mixtures. J. Sci. Food and Agric., 43: 361-372.

Case S.E., Capitani T., Whaley J.K., Shi Y.C., Trazsko P., Jeffcoat R. and Goldfarb H.B. (1998). Physical properties and gelation behavior of a low-amylopectin maize starch and other high- 
amylose maize starches. J. Cereal Sci., 27: 301-314.

Chau C.F. and Cheung P.C.K., (1998). Functional properties of flours prepared from three Chinese indigenous legume seeds. Food Chem., 61: 429-433.

Capanzana V.M., Labartine E.C., Dara-ug A.F.P. and Mariscal A., (2013). Physico-chemical and functional properties of coconut flour. FNRI Digest, 1. http://www.fnri.dost.gov.ph/ Assessed on 07-02-13.

Deshpande S.S. and Nielsen S.S., (1987). In vitro enzymatic hydrolysis of phaseolin, the major storage protein of Phaseolus vulgaris L. J. Food Sci., 52: 1326-1329.

Duranti M., (2006). Grain legume proteins and nutraceutical properties- Review. Fitoterapia, 77, 67-82.

Elsheikh E.A.E., El Tinay A.H. and Fadul I.A., (1999). Effect of nutritional status of faba

bean on proximate composition, anti-nutritional factors and in-vitro protein digestibility (IVPD). Food Chem., 67: 379-383.

Enwere N. J., (1998). Food of plant origin. Afro-Orbis Publishers Ltd. Nsukka, Nigeria. pp. 24-152.

Greer F.N. and Stewart B.A., (1959). Processing cassava and its products. FAO, Rome, Italy. pp. 84-85.

Hagenmier R., (1983). Dried coconut milk and other new foods from wet process. Coconuts Today, 1, 17-23.

Haines P., Guilkey D. and Popkin B., (1996). Trends in breakfast consumption of US Adults between 1965 and 1991. J Am Diet Assoc., 96: 464- 470.

Haralampu S.G., (2000). Resistant starch-a review of the physical properties and biological impact of $\mathrm{RS}_{3}$. Carbohydrate polymers, 41, 285-292.

Hogekamp S. and Schubert H., (2000). Agglomeration and agglomerator systems. In: F.J. Francis, ed. Wiley Encyclopedia of Food Science and Technology. New York: John Wiley and Sons. pp. 13-18.

Ihekoronye A. and Ngoddy P., (1985). Integrated Food Science and Technology for the Tropics. Macmillan Publishers Ltd, London. pp. 125210

Jena S. and Das H., (2007). Modelling for vacuum drying characteristics of coconut press cake. $J$. Food Eng., 79: 92-99.

Jones J.M., (2003). Cereal nutrition. In: Fast, E.R and Caldwell, E.F. (eds), Breakfast cereals and how they are made. USA: The American Association of Cereal Chemists. DOI:10.1094 AACC/27152-11

Kanu P.J., Sandy E.H., Kandeh B.A., Behsoon J.Z. and Huiming Z., (2009). Production and evaluation of breakfast cereal-based porridge mixed with sesame and pigeon peas for adults. Pak. J. Nutrition 8: 1335-1343.

Lin M.Y., Humbert E.S. and Sosulski F.W., (1974). Certain functional properties of sunflower meal product. J. Food Sci., 39: 368-370.

Maruatona G.K., (2008). Physico-chemical, nutritional and functional properties of defatted marama bean flour. An M.Sc. Dissertation. Department of Food Science, University of Pretoria, South Africa.

Matthey, F. P., and Hanna, M. A. (1997). Physical and functional properties of twin-screw extruded whey protein concentrate-corn starch blends. LWT-Food Science and Technology, 3 $O(4): 359-366$.

Mbaeyi I.E., (2005). Production and evaluation of breakfast cereal using pigeon-pea (Cajanus cajan) and sorghum (Sorghum bicolor L.) An M.Sc. Dissertation Department of Food Science and Technology, University of Nigeria, Nsukka.

McCarron J., (2011). Low acid diets. Livingstrong Foundation. pp. 1. http://www.livestrong.com /article/292174-low-acid-diets/ . Accessed on 13-02-13.

Okafor N. and Aniche G.N., (1980). Brewing a larger beer from Nigeria sorghum. J. Inst. Brew., 10, 32-35.

Okafor G.I. and Usman G.O., (2014). Production and evaluation of breakfast cereals from blends of African yam bean (Sphenostylis Stenocarpa), maize (Zea Mays), and defatted coconut (Cocus Nucifera). J. Food Proc. and Preserv. 38: 10371043. DOI: 10.1111 /jfpp. 12060.

Okaka J.C., (2005). Handling, Storage and Processing of Plant Foods. OJC Academic Publishers. Enugu, Nigeria. pp. 270-285.

Onweluzo J.C. and Nnamuchi O.M., (2009). Production and evaluation of porridge-type breakfast product from Treculia africana and Sorghum bicolor flours. Pak. J. Nutr., 8: 731736.

Onwuka G.I., (2005). Food Analysis and Instrumentation: Theory and Practice. Lagos: Naphthali Prints. pp. 1-219.

Padmashree T.S., Vijyalakshmi L. and Puttaray S., (1987). Effect of traditional processing on the functional properties of cowpea (Vigna catjang) flour. J. Food Sci. and Techn. 24:221225.

Parker R. and Ring S.G., (2001). Aspects of the physical chemistry of starch. J. Cer. Sci. 34: 117. 
Perez-Sira E.E., Lares M. and Gonzalez Z.M., (1987). Characterization of starch isolated from white and dark sorghum. Starch/Starke, 49: 103-106.

Rao M.A., (2007). Transport and Storage of Food Products. In: Heldman, D.R. and Lund, D.B. (eds), Handbook of food engineering. CRC Press Taylor and Francis Group LLB. Boca Raton, FL. pp. 353-395.

Sacchetti G., Pinnavaia G. G., Guidolin E., and DallaRosa M., (2004). Effects of extrusion temperature and feed composition on the functional, physical and sensory properties of chestnut and rice flour-based snack-like products. Food Res. Int., 37: 527-534.

Sahin S. and Sumnu S.G., (2006). Physical properties of foods. Springer Science + Business Media, LLC. New York. pp. 151-192.

Sanchez-Bel P., Egea I., Serrano M., Romojaro A. and Pretel M.T., (2012). Obtaining and storage of ready-to-use segments from traditional orange obtained by enzymatic peeling. Food Sci. and Tech. Inter., 18: 63-72.

Sanful R.E., (2009). Promotion of coconut in the production of yoghurt. Afr. J. Food Sci. 3: 147149.

Shi Y.C., Capitani T., Trzasko P. and Jeffcoat R., (1998). Molecular structure of a low amylopectin maize starch and other amylose maize starches. J. Cer. Sci., 27: 289-299.

Singh B.R. and Singh D.P., (1995). Agronomic and physiological responses of sorghum, maize and pearl millet to irrigation. Field Crops Res. 42:57-67.

Sivetz M. and Desrosier N., (1979). Hulling, classifying, storing, and grading green coffee beans. In: Sivetz M. and Desrosier N.W. (eds), Coffee technology. The Avi Publishing Company. Westport, CT. pp. 117-169.

Sultana Z., Ahmed S., Igbali S. and Chisty A.H., (2010). Determination of in vitro protein digestibility of different feed ingredients for Nilotica (Oreochromis nilotica). Bangladesh Res. Publ. J. 4: 87-94.

Taheri-Garavand A., Nassiri A. and Gharibzahedi S.M.T. (2012). Physical and mechanical properties of hemp seed. Int. Agrophys., 26: 211-215.

Udensi E.A., Arisa N.U. and Ikpa E., (2010). Effects of soaking and boiling and autoclaving on the nutritional quality of Mucuna flagellipes ("Ukpo"). Afr. J. Biochem. Res., 4:47-50.

Uguru M.I. and Madukaife S.O., (2001). Studies on the variability in the agronomic and nutritive characteristics of African yam bean (Sphenostylis stenocarpa). Plant Prod. and Res. J., 6:10-19.

Van der Poel A.F.B., (1990). Effect of processing on antinutritional factors (ANF) and protein nutritional value of dry beans (Phaseolus vulgaris L.) -A Review. In: Effects of processing on bean (Phaseolus vulgaris L.) protein quality. A Thesis submitted to Department of Animal Science, Agricultural University Wageningen, The Netherlands. pp. 19-53.

Van Soest P. V., Robertson J. B. and Lewis B. A., (1991). Methods for dietary fiber, neutral detergent fiber, and nonstarch polysaccharides in relation to animal nutrition. J. Dairy Sci., 74: 3583-3597.

Wasserman R., (2010). Properties of coconut fiber. http://www.livestrong.com/article/249254 properties-of-coconut fiber/. Accessed $19 / 8 / 10$.

Wu W., Williams W.P., Kunkel M.E., Acton J.C., Wardlaw F.B., Huang Y. and Grimes L.W., (1994). Thermal effects on net protein ratio of red kidney beans (Phaseolus vulgaris L.). J. Food Sci., 59: 1187-1191. 